\title{
PEMODELAN PENYEBARAN PENYEBARAN PENYAKIT FLU BURUNG
}

\author{
DEA DESDWIRIA PUTRI, MAHDHIVAN SYAFWAN \\ Program Studi Matematika, \\ Fakultas Matematika dan Ilmu Pengetahuan Alam, Universitas Andalas, \\ Kampus UNAND Limau Manis Padang, Indonesia, \\ dea.desdwiria@gmail.com
}

\begin{abstract}
Abstrak. Penyakit flu burung merupakan salah satu penyakit menular yang disebabkan oleh virus influensa $H 5 N 1$ dan sangat mudah bermutasi. Pada paper ini akan dijelaskan konstruksi model penyebaran penyakit flu burung pada populasi unggas dan populasi unggas-manusia. Dari model yang diperoleh kemudian dicari titik-titik kesetimbangannya. Selanjutnya dilakukan analisis kestabilan sistem di sekitar titik-titik kesetimbangan tersebut. Simulasi numerik untuk kasus endemik memberikan hasil yang sesuai dengan analisis kestabilan.
\end{abstract}

Kata Kunci: Model flu burung, titik kesetimbangan, analisis kestabilan, bilangan reproduksi dasar

\section{Pendahuluan}

Penyakit flu burung disebabkan oleh virus influensa tipe A dengan subtipe $H 5 N 1$ yang menyebar antar unggas dan dapat menular pada manusia. Bila dilihat sejarahnya, awal ditemukannya flu burung yaitu pada tahun 1878 di Italia dan diidentifikasi pada tahun 1955 sebagai virus Avian Influenza. Terjadi empat kali pandemi influensa pada abad ke-20 yaitu Spanish Flu (1918 - 1919), Asian Flu (1957 - 1958), Hongkong Flu (1968 - 1969), Russian Flu (1977) [1].

Indonesia merupakan negara di Asia yang tergolong rawan dalam peningkatan dan penyebaran penyakit flu burung. Hingga tahun 2014, di Indonesia telah tercatat 197 kasus flu burung dengan 165 merupakan kasus kematian [6]. Sejak tahun 2003, penyakit ini telah menyebar dari burung - burung di Asia ke Timur Tengah, Eropa dan Afrika. Manusia juga dapat terkena penyakit ini pada kasus-kasus tertentu, umumnya setelah berhubungan dengan unggas-unggas yang sakit. Sampai saat ini, diantara kasus penyakit flu burung pada manusia di berbagai daerah di dunia yang sudah tercatat, lebih dari 200 diantaranya meninggal dunia. Melihat kasus penyakit flu burung yang masih terus berkembang, tidak menutup kemungkinan penyakit flu burung menjadi penyebab pandemi influensa di dunia. Jika terjadi pandemi, tentu ini akan menjadi ancaman bagi dunia, termasuk Indonesia.

Dalam paper ini akan dibahas model penyebaran penyakit flu burung yang dapat digunakan sebagai salah satu cara untuk mengetahui pola penyebaran penyakit flu burung. Sebagian besar pembahasan pada paper ini merujuk pada [5]. 
2 Dea Desdwiria Putri, Mahdhivan Syafwan

\section{Tinjauan Pustaka}

Pandang sistem persamaan diferensial biasa orde satu,

$$
\mathbf{x}^{\prime}=\mathbf{f}(\mathbf{x})
$$

$\operatorname{dimana} \mathbf{x} \equiv \mathbf{x}(t)=\left[x_{1}(t), x_{2}(t), \cdots, x_{n}(t)\right]^{T} \operatorname{dan} \mathbf{f}(\mathbf{x})=\left[f_{1}(\mathbf{x}), f_{2}(\mathbf{x}), \cdots, f_{n}(\mathbf{x})\right]^{T}$

Definisi 2.1. Titik kesetimbangan dari sistem (2.1) adalah titik yang memenuhi persamaan

$$
\mathrm{x}^{\prime}=\mathbf{f}(\mathrm{x})=\mathbf{0}
$$

Jika solusi dari sistem (2.1) dimulai dari titik kesetimbangan, maka solusi itu selalu tetap berada pada titik tersebut (solusi konstan).

Sekarang pandang sistem

$$
\begin{aligned}
& x^{\prime}=f_{1}(x, y), \\
& y^{\prime}=f_{2}(x, y) .
\end{aligned}
$$

Misalkan titik $\left(x^{*}, y^{*}\right)$ merupakan titik kesetimbangan dari sistem tersebut. Sistem (2.2) di sekitar titik kesetimbangan $\left(x^{*}, y^{*}\right)$ dapat disajikan dalam bentuk matriks sebagai berikut

$$
\mathbf{v}^{\prime}=J \mathbf{v}
$$

dimana $\mathbf{v}=[x, y]^{T}$ dan

$$
J \equiv J\left(x^{*}, y^{*}\right)=\left(\begin{array}{ll}
\frac{\partial f_{1}\left(x^{*}, y^{*}\right)}{\partial x} & \frac{\partial f_{1}\left(x^{*}, y^{*}\right)}{\partial y} \\
\frac{\partial f_{2}\left(x^{*}, y^{*}\right)}{\partial x} & \frac{\partial f_{2}\left(x^{*}, y^{*}\right)}{\partial y}
\end{array}\right) .
$$

Matriks $J$ disebut matriks Jacobian dari sistem 2.2 yang dihitung di titik kesetimbangan $\left(x^{*}, y^{*}\right)$.

Kestabilan dari sistem 2.2 di sekitar titik kesetimbangan ditentukan oleh nilainilai eigen dari matriks Jacobiannya. Hubungan tersebut diberikan oleh teorema berikut.

Teorema 2.2. 4 Diberikan matriks Jacobian $J\left(x^{*}, y^{*}\right)$ dari sistem 2.2 dengan nilai eigen $\lambda$.

(a) Jika bagian riil dari semua nilai eigen dari matriks $J\left(x^{*}, y^{*}\right)$ bernilai negatif, maka titik kesetimbangan $\left(x^{*}, y^{*}\right)$ stabil asimtotik.

(b) Jika terdapat nilai eigen dari matriks $J\left(x^{*}, y^{*}\right)$ yang bagian riilnya bernilai positif, maka titik kesetimbangan $\left(x^{*}, y^{*}\right)$ tidak stabil.

Misalkan $A$ suatu matriks $n \times n$. Maka nilai eigen dari matriks tersebut, katakannlah $\lambda$, dapat ditentukan dengan menyelesaikan persamaan berikut:

$$
\operatorname{det}(\lambda I-A)=0 .
$$

Persamaan 2.4 disebut persamaan karakteristik atau polinomial karakteristik dari $A$ dan akar-akarnya merupakan nilai-nilai eigen dari matriks $A$. 
Teorema berikut memberikan kriteria agar akar-akar persamaan karakteristik (atau nilai-nilai eigen) bernilai riil negatif. Hal ini diperlukan untuk menentukan apakah suatu sistem bersifat stabil asimtotik atau tidak di sekitar titik kesetimbangannya, sebagaimana yang diberikan oleh Teorema 2.2 .

Teorema 2.3. [3](Kriteria Routh-Hurwitz) Misalkan $a_{1}, a_{2}, \cdots, a_{n}$ adalah bilangan riil dan tetapkan $a_{j}=0$ jika $j>n$. Maka semua akar polinomial

$$
p(z)=z^{n}+a_{1} z^{n-1}+\cdots+a_{n-1} z+a_{n}
$$

bernilai riil negatif jika dan hanya jika determinan

$$
M_{k}=\left[\begin{array}{ccccc}
a_{1} & a_{3} & a_{5} & \cdots & a_{2 k-1} \\
1 & a_{2} & a_{4} & \cdots & a_{2 k-2} \\
0 & a_{1} & a_{3} & \cdots & a_{2 k-3} \\
0 & 1 & a_{2} & \cdots & a_{2 k-4} \\
0 & 0 & a_{1} & \cdots & a_{2 k-5} \\
\vdots & \vdots & \vdots & \cdots & \vdots \\
0 & 0 & 0 & \cdots & a_{k}
\end{array}\right]
$$

untuk setiap $k=1,2, \cdots, n$, bernilai positif.

Berikut adalah teorema yang membahas tentang matriks blok $2 \times 2$ dan determinannya.

Teorema 2.4. [2] Jika $A$ dan D adalah matriks persegi, maka

$$
\operatorname{det}\left(\left[\begin{array}{ll}
A & 0 \\
C & D
\end{array}\right]\right)=\operatorname{det}(A) \operatorname{det}(D) \text {. }
$$

\section{Konstruksi Model dan Analisis Kestabilan}

\subsection{Konstruksi Model}

\subsubsection{Sistem Unggas}

Populasi unggas hanya dibagi menjadi dua kelompok yaitu unggas susceptible dan unggas infected. Model penyebaran penyakit flu burung untuk populasi unggas mengikuti model SI, yaitu [5]:

$$
\begin{aligned}
& X^{\prime}=c-b X-\omega X Y, \\
& Y^{\prime}=\omega X Y-(b+m) Y,
\end{aligned}
$$

$$
\begin{aligned}
\text { dengan } & \\
X \equiv X(t)= & \text { banyaknya unggas susceptible pada waktu } t, \\
Y \equiv Y(t)= & \text { banyaknya unggas infected pada waktu } t, \\
c & \text { jumlah kelahiran unggas setiap satuan waktu, } \\
= & \text { laju kematian alami unggas setiap satuan waktu, } \\
= & \text { laju interaksi antara unggas susceptible dengan unggas infected } \\
& \text { setiap satuan waktu yang menyebabkan penularan, } \\
= & \text { laju kematian unggas infected akibat penyakit flu burung setiap } \\
& \text { satuan waktu. }
\end{aligned}
$$




\subsubsection{Sistem Manusia}

Populasi manusia dibagi menjadi empat kelompok, yaitu manusia susceptible, manusia infected flu burung, manusia infected mutan flu burung dan manusia recovered. Model penyebaran flu burung pada populasi manusia mengikuti model $S I R$ berikut ini [5]:

$$
\begin{aligned}
& S^{\prime}=\lambda-\mu S-\beta_{1} S Y-\beta_{2} S H, \\
& B^{\prime}=\beta_{1} S Y-(\mu+d+\epsilon) B, \\
& H^{\prime}=\epsilon B+\beta_{2} S H-(\mu+\alpha+\gamma) H, \\
& R^{\prime}=\gamma H-\mu R .
\end{aligned}
$$

dengan

$$
\begin{aligned}
& S \equiv S(t) \quad=\quad \text { banyaknya manusia susceptible pada waktu } t \\
& B \equiv B(t) \quad=\quad \text { banyaknya manusia infected flu burung pada waktu } t, \\
& H \equiv H(t)=\text { banyaknya manusia infected mutan flu burung pada waktu } t \text {, } \\
& R \equiv R(t) \quad=\quad \text { banyaknya manusia recovered pada waktu } t \text {, } \\
& \lambda \quad=\text { jumlah kelahiran manusia setiap satuan waktu, } \\
& \mu \quad=\text { laju kematian alami manusia setiap satuan waktu, } \\
& \beta_{1}=\text { laju interaksi antara manusia susceptible dengan unggas infected } \\
& \text { setiap satuan waktu yang menyebabkan penularan, } \\
& \beta_{2} \quad=\text { laju interaksi antara manusia susceptible dengan manusia infected } \\
& \text { mutan flu burung setiap satuan waktu yang menyebabkan penu- } \\
& \gamma=\text { laju penyembuhan manusia infected mutan flu burung, } \\
& \epsilon \quad=\text { laju mutasi, } \\
& d \quad=\text { laju kematian manusia infected flu burung akibat penyakit flu }
\end{aligned}
$$

Dengan menggabungkan penyebaran model penyakit flu burung yang terjadi pada populasi unggas dan populasi manusia, maka model penyebaran penyakit flu burung pada populasi unggas-manusia mengikuti model $S I-S I R$ berikut ini:

$$
\begin{aligned}
& X^{\prime}=c-b X-\omega X Y, \\
& Y^{\prime}=\omega X Y-(b+m) Y, \\
& S^{\prime}=\lambda-\mu S-\beta_{1} S Y-\beta_{2} S H, \\
& B^{\prime}=\beta_{1} S Y-(\mu+d+\epsilon) B, \\
& H^{\prime}=\epsilon B+\beta_{2} S H-(\mu+\alpha+\gamma) H, \\
& R^{\prime}=\gamma H-\mu R .
\end{aligned}
$$

Pada model di atas, semua parameter bernilai positif dan nilai $\epsilon$ cukup kecil. Selain itu, nilai $b$ jauh lebih besar dari $\mu(b \gg \mu)$. Selanjutnya, karena perbedaan virulensi (yaitu kemampuan virus untuk menyebabkan penyakit) nilai $\alpha$ kurang dari $d$ dan nilai $d$ kurang dari $m(m>d>\alpha)$. 
3.2. Analisis Kestabilan Model

\subsubsection{Sistem Unggas}

Titik kesetimbangan pada sistem unggas dapat ditentukan dengan menetapkan $X$ dan $Y$ sebagai fungsi konstan (tidak bergantung pada waktu $t$ ), sehingga diperoleh dua titik kesetimbangan pada sistem unggas, yaitu:

- $e_{0}=\left(X_{0}, 0\right)$ dimana $X_{0}=\frac{c}{b}$, yang merupakan titik kesetimbangan bebas penyakit.

- $e_{+}=\left(X^{*}, Y^{*}\right)$ dimana $X^{*}=\left(\frac{b+m}{\omega}\right)$ dan $Y^{*}=\left(\frac{c}{b+m}-\frac{b}{\omega}\right)$, yang merupakan titik kesetimbangan endemik.

Bilangan reproduksi dasar untuk penyakit flu burung pada populasi unggas $\left(r_{0}\right)$, didefinisikan sebagai banyaknya unggas susceptible yang terinfeksi akibat tertular dari unggas lain yang telah terinfeksi. Laju dimana satu unggas menginfeksi unggas baru diberikan oleh $\omega X$. Jika semua unggas susceptible maka $X=\frac{c}{b}$. Karena waktu hidup dari unggas yang terinfeksi adalah $\frac{1}{b+m}$, maka bilangan reproduksi dasar $r_{0}$ adalah

$$
r_{0}=\frac{\omega X}{b+m}=\frac{c \omega}{b(b+m)}
$$

Berikut merupakan teorema yang menjelaskan syarat cukup kestabilan dari sistem unggas di sekitar titik-titik kesetimbangannya.

Teorema 3.1. 5] Jika $r_{0}<1$, maka $e_{0}$ stabil asimtotik. Jika $r_{0}>1$, maka $e_{+}$ stabil asimtotik.

Bukti. Matriks Jacobian yang bersesuaian dengan sistem 3.1 adalah

$$
J=\left(\begin{array}{cc}
-b-\omega Y & -\omega X \\
\omega Y & \omega X-(b+m)
\end{array}\right) .
$$

Pada titik kesetimbangan $e_{0}=\left(\frac{c}{b}, 0\right)$, nilai-nilai eigen dari matriks Jacobian (3.4) adalah $-b$ dan $\omega\left(\frac{c}{b}\right)-b-m$. Jika $r_{0}=\frac{c \omega}{b(b+m)}<1$ maka $\frac{c \omega}{b}-(b+m)<0$. Jadi, $e_{0}$ stabil asimtotik.

Selanjutnya pada titik kesetimbangan $e_{+}=\left(X^{*}, Y^{*}\right)$, nilai-nilai eigen $p$ diperoleh dari persamaan karakteristik

$$
p^{2}+\left\{2 b+m+\omega\left(Y^{*}-X^{*}\right)\right\} p+b(b+m)+b \omega\left(Y^{*}-X^{*}\right)+m \omega Y^{*}=0 .
$$

Jika $r_{0}=\frac{c \omega}{b(b+m)}>1$, maka $c \omega-b(b+m)>0$, sehingga berlaku

$$
2 b+m+\omega\left(Y^{*}-X^{*}\right)>0 \text { dan } b(b+m)+b \omega\left(Y^{*}-X^{*}\right)+m \omega Y^{*}>0 .
$$

Karena semua koefisien dari persamaan karakteristik (3.5) bernilai positif, maka $e_{+}$ adalah stabil asimtotik. 


\subsubsection{Sistem Unggas-Manusia}

Titik kesetimbangan pada populasi unggas-manusia yang diberikan oleh sistem (3.3) ditentukan dengan menetapkan $X, Y, S, B, H$ dan $R$ sebagai fungsi-fungsi konstan (tidak bergantung pada waktu) sehingga diperoleh tiga titik kesetimbangan berikut:

- $E_{0}=(X, Y, S, B, H, R)=\left(\frac{c}{b}, 0, \frac{\lambda}{\mu}, 0,0,0\right)$, yang merupakan titik kesetimbangan bebas penyakit.

- $E_{b}=(X, Y, \widetilde{S}, B, \widetilde{H}, \widetilde{R})=\left(\frac{c}{b}, 0, \frac{\mu+\alpha+\gamma}{\beta_{2}}, 0,\left(\frac{\lambda}{\mu+\alpha+\gamma}-\frac{\mu}{\beta_{2}}\right), \frac{\gamma}{\mu} \widetilde{H}\right)$, yang merupakan titik kesetimbangan endemik manusia.

- $E_{+}=\left(X^{*}, Y^{*}, S^{*}, B^{*}, H^{*}, R^{*}\right)$, yang merupakan titik kesetimbangan endemik penuh, dimana

$$
\begin{aligned}
H^{*}= & \frac{-\left[\left(\mu+\beta_{1} Y^{*}\right)(\mu+\alpha+\gamma)-\beta_{2} \lambda\right]}{2 \beta_{2}(\mu+\alpha+\gamma)} \\
& +\frac{\sqrt{\left[\left(\mu+\beta_{1} Y^{*}\right)(\mu+\alpha+\gamma)-\beta_{2} \lambda\right]^{2}-4\left(\beta_{2}(\mu+\alpha+\gamma)\right)\left(\frac{\epsilon \beta_{1} \lambda Y^{*}}{\mu+d+\epsilon}\right)}}{2 \beta_{2}(\mu+\alpha+\gamma)} \\
S^{*}= & \frac{\lambda}{\mu+\beta_{1} Y^{*}+\beta_{2} H^{*}}, \\
B^{*}= & \frac{\beta_{1} S^{*} Y^{*}}{\mu+d+\epsilon}, \\
R^{*}= & \frac{\gamma}{\mu} H^{*}
\end{aligned}
$$

Bilangan reproduksi dasar untuk penyakit flu burung yang telah bermutasi pada populasi manusia $\left(R_{0}\right)$, didefinisikan sebagai banyaknya manusia susceptible yang terinfeksi akibat tertular dari manusia yang terinfeksi mutan flu burung. Laju infeksi manusia yang terinfeksi mutan flu burung adalah $\beta_{2} S$. Jika semua manusia susceptible, maka $S=\frac{\lambda}{\mu}$. Waktu hidup manusia yang terinfeksi mutan flu burung adalah $\frac{1}{\mu+\alpha+\gamma}$. Jadi

$$
R_{0}=\frac{\beta_{2} S}{\mu+\alpha+\gamma}=\frac{\beta_{2} \lambda}{\mu(\mu+\alpha+\gamma)}
$$

Berikut adalah teorema yang menjelaskan syarat cukup kestabilan titik kesetimbangan pada populasi unggas-manusia.

Teorema 3.2. [5] Jika $r_{0}<1$ dan $R_{0}<1$, maka $E_{0}$ stabil asimtotik. Jika $r_{0}<1$ dan $R_{0}>1$, maka $E_{b}$ stabil asimtotik. Jika $r_{0}>1$, maka $E_{+}$stabil asimtotik.

Bukti. Matriks Jacobian yang bersesuaian dengan sistem unggas-manusia adalah

$$
J=\left(\begin{array}{ll}
B & 0 \\
C & A
\end{array}\right)
$$


dimana

$$
B=\left(\begin{array}{cc}
-b-\omega Y & -\omega X \\
\omega Y & \omega X-(b+m)
\end{array}\right), \quad C=\left(\begin{array}{cc}
0 & -\beta_{1} S \\
0 & \beta_{1} S \\
0 & 0 \\
0 & 0
\end{array}\right)
$$

dan

$$
A=\left(\begin{array}{cccc}
-\mu-\left(\beta_{1} Y+\beta_{2} H\right) & 0 & -\beta_{2} S & 0 \\
\beta_{1} Y & -(\mu+d+\epsilon) & 0 & 0 \\
\beta_{2} & \epsilon & \beta_{2} S-(\mu+\alpha+\gamma) & 0 \\
0 & 0 & \gamma & -\mu
\end{array}\right)
$$

Perhatikan bahwa $J$ adalah matriks blok, sehingga $(J-\lambda I)$ juga matriks blok. Berdasarkan Teorema 2.4 $\operatorname{det}(J-\lambda I)$ diberikan oleh

$$
\operatorname{det}(J-\lambda I)=\operatorname{det}(B-\lambda I) \operatorname{det}(A-\lambda I) .
$$

Berdasarkan Teorema 3.1, submatriks $B$ di titik kesetimbangan $E_{0}$ dan $E_{b}$ mempunyai nilai eigen riil negatif jika $r_{0}<1$ dan di titik kesetimbangan $E_{+}$mempunyai nilai eigen riil negatif jika $r_{0}>1$. Selanjutnya syarat cukup lainnya untuk kestabilan titik-titik kesetimbangan tersebut dapat ditentukan dengan menyelidiki nilai-nilai eigen dari submatriks $A$. Berikut akan ditinjau kestabilan setiap titik kesetimbangan.

- Untuk titik $E_{0}=\left(\frac{c}{b}, 0, \frac{\lambda}{\mu}, 0,0,0\right)$, nilai-nilai eigen dari submatriks $A$ adalah $-\mu,-(\mu+d+\epsilon)$, dan $\frac{\beta_{2} \lambda}{\mu}-(\mu+\alpha+\gamma)$. Jika $R_{0}=\frac{\beta_{2} \lambda}{\mu(\mu+\alpha+\gamma)}<1$ maka $\frac{\beta_{2} \lambda}{\mu}-(\mu+\alpha+\gamma)<0$. Jadi jika $r_{0}<1$ dan $R_{0}<1$, maka $E_{0}$ stabil asimtotik.

- Untuk titik $E_{b}=\left(\frac{c}{b}, 0, \frac{\mu+\alpha+\gamma}{\beta_{2}}, 0,\left(\frac{\lambda}{\mu+\alpha+\gamma}-\frac{\mu}{\beta_{2}}\right), \frac{\gamma}{\mu} \widetilde{H}\right)$, nilai-nilai eigen $p$ diperoleh dari persamaan karakteristik

$$
f(p)=(p+\mu+d+\epsilon)\left(p^{2}+a_{0} p+a_{1}\right)=0
$$

dimana

$$
a_{0}=\frac{\beta_{2} \lambda}{\mu+\alpha+\gamma}, \quad a_{1}=\beta_{2} \lambda-\mu(\mu+\alpha+\gamma) .
$$

Dari persamaan karakteristik tersebut, diperoleh nilai-nilai eigen $p_{1}, p_{2}, p_{3}$, dimana $p_{1}=-(\mu+d+\epsilon)$ dan $p_{2}, p_{3}$ merupakan akar-akar dari persamaan $p^{2}+a_{0} p+a_{1}=0$, dengan $a_{0}=\frac{\beta_{2} \lambda}{\mu+\alpha+\gamma}>0$ dan $a_{1}=\beta_{2} \lambda-\mu(\mu+\alpha+\gamma)$. Jika $R_{0}=\frac{\beta_{2} \lambda}{\mu(\mu+\alpha+\gamma)}>1$, maka $a_{1}>0$. Jadi, jika $r_{0}<1$ dan $R_{0}>1$, maka $E_{b}$ stabil asimtotik.

- Untuk titik $E_{+}=\left(X^{*}, Y^{*}, S^{*}, B^{*}, H^{*}, R^{*}\right)$, nilai-nilai eigen $p$ diperoleh dari persamaan karakteristik

$$
f(p)=p^{3}+a_{0} p^{2}+a_{1} p+a_{2}=0 .
$$


dimana

$$
\begin{aligned}
a_{0}= & \mu+\beta_{1} Y^{*}+\beta_{2} H^{*}+\mu+d+\epsilon+\frac{\epsilon B^{*}}{H^{*}}, \\
a_{1}= & \left(\mu+\beta_{1} Y^{*}+\beta_{2} H^{*}\right)(\mu+d+\epsilon)+(\mu+d+\epsilon) \frac{\epsilon B^{*}}{H^{*}} \\
& +\left(\mu+\beta_{1} Y^{*}+\beta_{2} H^{*}\right) \frac{\epsilon B^{*}}{H^{*}}+\beta_{2}{ }^{2} S^{*} H^{*}, \\
a_{2}= & \left(\mu+\beta_{1} Y^{*}+\beta_{2} H^{*}\right)(\mu+d+\epsilon) \frac{\epsilon B^{*}}{H^{*}}+\beta_{1} \beta_{2} \epsilon S^{*} Y^{*} \\
& +\beta_{2}{ }^{2} S^{*} H^{*}(\mu+d+\epsilon) .
\end{aligned}
$$

Perhatikan bahwa semua koefisien $a_{i}(i=0,1,2)$ positif dan $a_{0} a_{1}-a_{2}>0$, sehingga berdasarkan kriteria Routh-Hurwitz, semua nilai eigen bernilai riil negatif. Jadi, jika $r_{0}>1, E_{+}$stabil asimtotik.

\section{Simulasi Numerik}

Simulasi numerik pada paper ini bertujuan untuk melihat penyebaran penyakit flu burung pada populasi unggas dan populasi unggas-manusia. Adapun jumlah populasi awal ditetapkan sebagai berikut:

$$
X(0)=10, \quad Y(0)=2, \quad S(0)=100, \quad B(0)=0, \quad H(0)=0, \text { dan } R(0)=0 .
$$

Sedangkan nilai-nilai parameter ditetapkan sebagai berikut. $c=26,5, \quad b=5$, $m=5, \quad \omega=2, \quad \lambda=3, \quad \mu=0,015, \quad d=1, \quad \alpha=0,06, \quad \beta_{1}=0,2, \quad \beta_{2}=0,003$, $\gamma=0,01$ dan $\epsilon=0,001$.

Dengan menggunakan nilai-nilai parameter tersebut, diperoleh bilangan reproduksi dasar untuk populasi unggas, $r_{0}=1,06 \quad\left(r_{0}>1\right)$ dan populasi unggasmanusia, $R_{0} \approx 7,1 \quad\left(R_{0}>1\right)$. Selanjutnya diperoleh titik-titik kesetimbangan untuk sistem unggas, $e_{0}=(5,3 ; 0)$ dan $e_{+}=(5 ; 0,15)$. Sedangkan pada sistem unggasmanusia, diperoleh titik-titik kesetimbangan $E_{0}=(5,3 ; 0 ; 200 ; 0 ; 0 ; 0),, \quad E_{b}=$ $\left(5,3 ; 0 ; 1,0083 \times 10^{3} ; 30,29 ; 20,196\right), 6$ dan $E_{+}=(5 ; 0,15 ; 28,32 ; 0,84 ; 20,31 ; 13,54)$.

Dengan menyelesaikan sistem (3.1) dan 3.3 secara numerik (dalam hal ini digunakan metode Runge-Kutta orde 4) untuk nilai-nilai parameter dan jumlah populasi awal tersebut, diperoleh kurva solusi untuk masing-masing populasi yang diberikan pada Gambar 1 dan 2. 


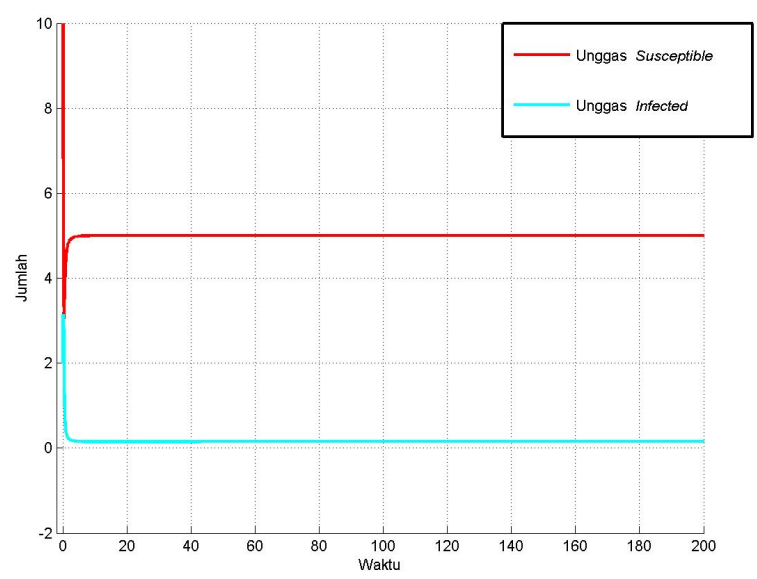

Gambar 1. Grafik solusi model penyebaran penyakit flu burung pada populasi unggas.

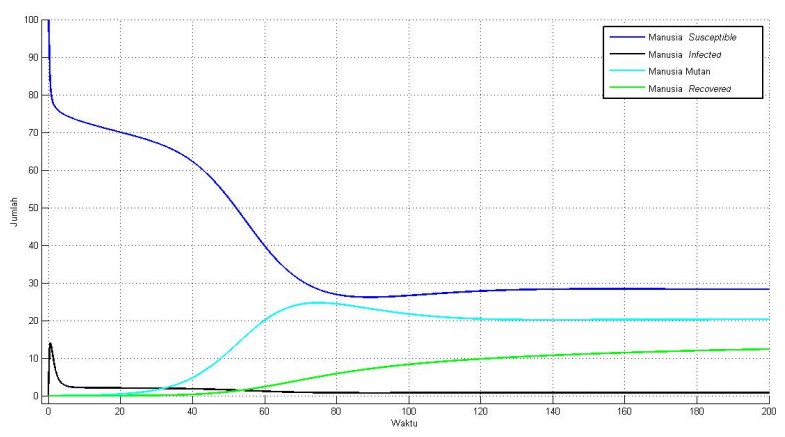

Gambar 2. Grafik solusi model penyebaran penyakit flu burung pada populasi manusia.

Dari simulasi dapat dilihat bahwa kasus flu burung pada populasi unggas dan populasi unggas-manusia menuju ke titik kesetimbangan endemik yaitu $e_{+}$dan $E_{+}$.

\section{Kesimpulan}

Model penyebaran penyakit flu burung dikontruksi berdasarkan dua kelompok populasi, yaitu populasi unggas dan populasi campuran unggas-manusia. Model pada populasi unggas mengikuti model $S I$ sedangkan model pada populasi unggasmanusia mengikuti model SI-SIR.

Selanjutnya diperoleh dua titik kesetimbangan pada sistem unggas yaitu $e_{0}$ (bebas penyakit) dan $e_{+}$(endemik). Sedangkan titik-titik kesetimbangan pada sistem unggas-manusia ada tiga yaitu $E_{0}$ (bebas penyakit), $E_{b}$ (endemik manusia), dan $E_{+}$(endemik penuh). 
Untuk mengetahui tingkat penyebaran penyakit flu burung, digunakan suatu ukuran yang disebut bilangan reproduksi dasar ( $r_{0}$ untuk sistem unggas dan $R_{0}$ untuk sistem unggas-manusia). Dari analisis kestabilan di sekitar titik-titik kesetimbangan pada sistem unggas diperoleh jika $r_{0}<1$, maka $e_{0}$ stabil asimtotik sedangkan jika $r_{0}>1$, maka $e_{+}$stabil asimtotik. Selanjutnya dari analisis kestabilan di sekitar titik-titik kesetimbangan pada sistem unggas-manusia didapatkan jika $r_{0}<1$ dan $R_{0}<1$, maka $E_{0}$ stabil asimtotik, jika $r_{0}<1$ dan $R_{0}>1$, maka $E_{b}$ stabil asimtotik dan jika $r_{0}>1$, maka $E_{+}$stabil asimtotik.

Dengan menggunakan nilai-nilai parameter tertentu seperti yang dijelaskan pada simulasi numerik, diperoleh $r_{0}=1,06\left(r_{0}>1\right)$ dan $R_{0} \approx 7,1\left(R_{0}>1\right)$. Hal ini menunjukan bahwa kasus penyakit flu burung berpotensi menjadi endemik di kedua populasi tersebut. Dari simulasi yang dilakukan dengan menggunakan nilai-nilai parameter tersebut, diperoleh hasil yang sesuai dengan analisis kestabilan, yaitu kurva solusi untuk sistem unggas menuju ke titik $e_{+}$(stabil asimtotik) dan kurva solusi untuk sistem manusia menuju ke titik $E_{+}$(stabil asimtotik).

Untuk penelitian selanjutnya, penulis menyarankan hal-hal berikut:

(1) Mengembangkan model flu burung dengan mempertimbangkan faktor-faktor lainnya, seperti pemberian vaksinasi.

(2) Perlu dilakukan analisis lebih lanjut tentang kestabilan di sekitar titik kesetimbangan.

\section{Daftar Pustaka}

[1] Anonim. 2012. Sejarah Flu Burung. http://devawisnu23.wordpress.com/ 2012/03/19/sejarah-penyebaran-virus-flu-burung-faktor-penyebabterjadinya-fluburung/,. Diakses pada 2 September 2014.

[2] Abadir, Karim M. and John R. Magnus. 2005. Matrix Alegbra. Cambridge University Press, New York.

[3] Fisher, S. D. 1990. Complex Variables Second Edition. Wadsworth and software. Pacific Grove.California.

[4] Olsder, G.J. 1994. Mathematics System Theory. The Netherlands: Delftse Uitgevers Maatscappij b.v.

[5] Shingo, I., Y. Takeuchi and X. Liu. 2006. Avian - human influenza epidemic model. Mathematical Biosciences. 207 (1): 1-25.

[6] WHO. Tanpa Tahun. Database of Avian Influenza. http://www . who.int,. Diakses pada 1 April 2015. 